\title{
Empirical Evidence on Sources of Consumer Trust on E-Commerce of Ghana
}

\author{
Benjamin Adjei Danquah* \\ ${ }^{1}$ School of Economics \\ Wuhan University of Technology \\ Wuhan, China \\ ${ }^{2}$ Faculty of Business and Management Studies \\ Kumasi Technical University, \\ Kumasi, Ghana \\ danquah50@yahoo.com
}

\author{
Chen lin Dong \\ School of Economics \\ Wuhan University of Technology \\ Wuhan, China \\ chendl@whut.edu.cn
}

\begin{abstract}
The emergence of E-commerce is taking the world by storm and is growing rapidly in developed and some emerging economies. The purpose of the research was to assess the impact on sources of consumer trust on E-Commerce in Ghana. The study adopted primary data using 215 questionnaires for the survey and uses SEM - AMOS for its analysis. The results projected that Customer Satisfaction, Service Quality and Brand Recognition have much impact on the E-Commerce growth in Ghana. Industrial players in Ghana should focus their policy direction on building a strong brand, improving the service delivery and striving to meet the customer at their desirable point
\end{abstract}

Keywords-E-Commerce; Trust; Service quality; Brand recognition; Customer satisfaction

\section{INTRODUCTION}

Due to globalization and transformation with its effects on outsourcing and offshoring of businesses, the trend in international traveling and immigration has changed worldwide. The upsurge in the growth of e-commerce EC) and subsequently it spread, by eliminating all trade barriers of proximity. Nonetheless, there are certain concerns in the EC environment such as trust, security, order fulfilment, etc. that go beyond visual and appealing of products on website. Currently, both consumers and retailers are engaging in omnichannel approaches to e-commerce like shopping both online and in-store. The global world today is a whole market for ecommerce where consumers get access to products and services they need in everyplace and everywhere with little regard to the restrictions of spatial distance or proximity. Ecommerce is transforming businesses and it is touted as a vibrant tool to businesses bringing along with its efficient and lower cost benefits. B2C e-commerce is changing businesses across the world and increasing significantly the GDPs of some economies. According to Kearney [1], retail e-commerce was US\$840 billion in 2014 exceeding the sales of US\$695 billion in year 2013 and it was projected to surge to US\$1506 billion in 2018. Collective data gathered within The Enterprise Guide to Global Ecommerce forestalls a $246.15 \%$ surge in global ecommerce sales from 2014 of $\$ 1.3$ trillion to 2021 of $\$ 4.5$ trillion [2].

E-commerce communications are the sales of products and services over the internet which in the past decades have been growing massively. Nonetheless, E-commerce is still a comparatively new concept for most people in the developing countries and as trust rises with familiarity, it is key to find ways to galvanized consumers to constantly use e-commerce [3]. The competition has also developed glaring in this segment and owing to this intensified competition, online retailers are more worried to find methods to entice customers to their websites [4].

Arguing without empirical evidence about what is happening in the well-known economy is not the same as what is happening in the developing countries such as Ghana is mute. Comparative studies from an emerging nations' standpoints are narrow and therefore there is a call for studies into this regard [5][6]; hence, a research in a developing country such as Ghana will generate new insights. The digital opening of e-commerce acceptance among nations is broadening and more researches such as this one will profit developing nations in taking full advantage of the benefits in e-commerce. Ghana is a developing country that has recently joined the group of nation defined as a middle class with per capita income of 47.93 US dollars with projected average of 4 to 6 percent for 2014 to 2024 in per capita growth rate. [8]. Also, 46 percent of Ghanaians are categorized within the middle income bracket, as compared to the Africa average of 34.3 percent [9]. As the number of Ghanaians in the middle income rises, the pool of nationals with disposable income also increases. This is a good indicator of e-commerce growth.

It may be argued that foreign e-commerce firms may likely to fail where they do not appreciate the consumer trust aspects and sources of trust within the community of their operations [7]. The purpose of this study is to measure the sources of trust on intention to purchase in e-commerce of Ghana. The current research is to identify factors that will build confidence in ecommerce in Ghana and also to increase the frequency of online purchases. Some recent investigations empirically established some of these sources of consumer trust but in all these studies, the emphasis was on just one or a pair of sources of trust in a developed country.

\section{REVIEW OF LITERATURE}

As [10] has argued, the buying behaviours of on-line purchasers play a vital role in the realization of e-retailers. If 
we can classify the aspects that sway the consumer's buying decision, e-retailers will be capable to design their marketing schemes accordingly to capitalize on customer experience to enlarge total sales. Customer service is not a new theory but nowadays companies can use the new technologies to improve. The significance that is set to these beliefs and the consumers' attitudes concerning e-commerce are prejudiced by the degree to which they consider online shopping to be a decent experience [11]; and the trust stance - as consumers are rational and are affected by their awareness of trust in a dealer, they only share individual and delicate information with a web dealer when they trust positive aspects of the site [12]. The hypothesis that trust stance and attitude towards online shopping has positive effect on the intention to purchase.

The professed reputation of a buyer has shown to be significantly connected to consumers trust in the vendor. Consumers are open to the realities that are fashioned by the firm and they may knowingly or reflexively select facts that are well-suited with their formation of attitude and beliefs. These facts are recollected and salvaged from memory to reenact an image when firm is brought to mind which reveals brand recognition. So reputation and brand recognition have direct relationship with intention to purchase.

Content quality is vastly influenced by these customer approaches and interfaces, and they are the motives why satisfaction is an actual consumer condition which result from a worldwide calculation of all the facets which make up consumer relationship. Purpose of shopping online is linked to internet shopping history and has an optimistic effects on consumer behaviour. Understanding how previous involvement affects purchasing behaviour is imperative, given that earlier ecommerce consumers acted contrarily to new consumers. Therefore, it can affirmed that service quality and customer satisfaction positively influence intention to purchase.

However, the recent works of [15], captured the electronic word of mouth (eWOM). It is said to be the most trusted source of information and trust antecedents for consumer in the context of e-commerce which were ignored by many western and non-western researchers.

\section{METHODOLOGY}

This study adopted a survey as an appropriate method and [13] also asserted that it is apposite to use surveys where the source of a phenomenon is being grounded. The sampling frame was guided by the studies that have proven that consumers who are predisposed to internet will probably participate in online shopping [14]. Data for the research was prudently collected in efficient manner with the use of questionnaires. Advanced quantitative analysis was also done by means of structural equation model - Analysis of Moment Structures (AMOS) for the modeling. MS Excel was used to check the data quality by means of the count blank function and the standard deviations. This is because it is virtually a new path analysis to determine the extent of consumer sources of trust on e-commerce of a small developing country like Ghana. The regression method was chosen because the studies was to measure the impact of sources of trust on the intention to purchase. We settle on linear regression because of the new nature of e-commerce in Ghana. Equation (1) shows the linear regression below:

$I P=\beta_{0}+\beta_{1} C S+\beta_{2} A T O S+\beta_{3} T S+\beta_{4} R E P+\beta_{5} S Q+\beta_{6} B R+\varepsilon_{t}$

Where $\mathrm{CS}=$ consumer characteristics, ATOS $=$ attitude towards online shopping, TS $=$ trust stance, $\mathrm{REP}=$ reputation, $\mathrm{SQ}=$ service quality, $\mathrm{BR}=$ brand recognition and $\varepsilon_{\mathrm{t}}=$ error term. The coefficients of the variables are represented $\beta$. These variables were chosen because of various studies that established their contribution to intention to purchase.

\section{Data And Data Analysis}

The sample was taken from the people residing in Ghana and the total questionnaires distributed and screened carefully to satisfy the requirement was 215 . This represent about 66.5 percent of the questionnaires response rate. The response rate was actually good in relations to this type of research. The respondents were made up of $131(60.9 \%)$ male and $84(39.1 \%)$ females. The highest age brackets involved were between ages $20-29$ representing $52 . \%$ and ages $30-39$ representing $33.7 \%$. This shows that the ages below 40 years were much represented $(85.7 \%)$ and that means the youth showed much more interest in E-Commerce than the adult population. In terms of education, majority of the respondents were either holding diploma or bachelor degrees (79.5) and rest were spread across the various level of education.

The Table 1 shows the reliability items output of Cronbach's Alpha and Confirmatory Factor Analysis loadings. The output proved that there is an internal consistency between the construct of 24 items in the questionnaire related to the sources of trust on E-Commerce of Ghana. The Overall Cronbach's Alpha for the instrument (questionnaire) is 0.829 . It also shows a positive correlation between items in the instrument. The CFA loadings of instrument shows content and construct validity with CFA value greater than 0.80 . It shows that all 24 items constructed in the questionnaire is confirm its validity. The composite reliability of the six factors extracted ranges from $0.72-0.90$, above the acceptable rule value of 0.70 . This confirms that the model is internally reliable. AVE measures the convergent validity which accept values above 0.5 , the output results ranges from $0.51-0.56$. This is an indication that there is a convergent validity in the estimated model.

TABLE I. RELIABILITY ANALYSIS

\begin{tabular}{|l|l|l|}
\hline \multicolumn{1}{|c|}{ Construct } & $\begin{array}{c}\text { Number of } \\
\text { Items }\end{array}$ & $\begin{array}{c}\text { Cronbach's } \\
\text { Alpha }\end{array}$ \\
\hline TS & 4 & 0.757 \\
\hline ATOS & 4 & 0.827 \\
\hline REP & 3 & 0.810 \\
\hline BR & 5 & 0.851 \\
\hline SQ & 4 & 0.841 \\
\hline CS & 4 & 0.885 \\
\hline
\end{tabular}


The results in table II shows that the predictors can explain the model or the behavior of E-Commerce on Ghana. Fifty-two percent $(52 \%)$ of the behavior is explained by the predictors in the model. The predictors were CS, ATOS, TS, REP, SQ and BR. The mean square is 30.781 with F-Statistics of 115.199 was statistically significant at one percent level. The cumulative effect (ANOVA) was perfect and significant at one percent level. Both standardized and unstandardized coefficients were measured to see their impact of their effects. The standardized coefficients do not depart from the unstandardized coefficients.

Trust Stance (TS) explains about 8 percent of the variation in the E-Commerce of Ghana. Attitude Towards Online Shopping (ATOS) explains about 2 percent of both the positive and negative effects on E-Commerce of Ghana. Also Reputation (REP) explains 5 percent of the impact on variations in the E-Commerce situation in Ghana. Their weights were not statistically significant at 5 percent level. The purpose was to measure their impact in E-Commerce situation of the country. Brand Recognition (BR) explains about 14 percent of the variation in E-Commerce in Ghana. Moreover, Service Quality (SQ) explains about 25 percent of the cause and effect of E-Commerce in Ghana. The highest reporting was Customer Satisfaction (CS) showing about 31 percent of the variations. Brand Recognition, Customer Satisfaction and Service Quality were statistically significant at one percent level. All the hypothesis postulated for the studies were achieved.

TABLE II. IMPACT OF CONSUMER TRUST ON E-COMMERCE OF GHANA

\begin{tabular}{|c|c|c|c|c|c|}
\hline \multicolumn{6}{|c|}{ Model Summary } \\
\hline $\boldsymbol{R}$ & R Square & Adjusted R Square & Std. Error of the Estimate & & \\
\hline $.726 \mathrm{a}$ & .527 & .522 & .51691 & & \\
\hline \multicolumn{6}{|c|}{ a. Predictors: (Constant), CS, ATOS, TS, REP, SQ, BR } \\
\hline \multicolumn{6}{|c|}{ ANOVA } \\
\hline & Sum of Squares & $d f$ & Mean Square & $F$ & Sig. \\
\hline Regression & 184.684 & 6 & 30.781 & 115.199 & $.000^{\mathrm{b}}$ \\
\hline Residual & 165.929 & 621 & .267 & & \\
\hline Total & 350.613 & 627 & & & \\
\hline
\end{tabular}

ttb. Predictors: (Constant), CS, ATOS, TS, REP, SQ, BR

\begin{tabular}{|c|c|c|c|c|c|}
\hline \multicolumn{6}{|c|}{ Coefficients } \\
\hline & \multicolumn{2}{|c|}{ Unstandardized Coefficients } & \multirow{2}{*}{$\begin{array}{c}\text { Standardized Coefficients } \\
\text { Beta }\end{array}$} & \multirow{2}{*}{$t$} & \multirow{2}{*}{ Sig. } \\
\hline & B & Std. Error & & & \\
\hline (Constant) & .640 & .129 & & 4.947 & .000 \\
\hline TS & .085 & .042 & .078 & 2.042 & .042 \\
\hline ATOS & .018 & .033 & .019 & .537 & .592 \\
\hline REP & .051 & .039 & .054 & 1.290 & .198 \\
\hline BR & .135 & .044 & .142 & 3.059 & .002 \\
\hline SQ & .249 & .042 & .247 & 5.951 & .000 \\
\hline CS & .302 & .044 & .314 & 6.800 & .000 \\
\hline
\end{tabular}




$$
I P=0.64+0.31 C S+0.02 \text { ATOS }+0.08 T S
$$

$$
+0.05 R E P+0.25 S Q+0.14 B R
$$

Equation (2) above shows the coefficients or the weights of the variables used in the study

Stakeholders of E-Commerce in Ghana must pay more attention to Brand Recognition, Customer Satisfaction and Service Quality in order to be successful in their activities and also expand their business. Their total effect on E-Commerce is very enormous in the region of about 70 percent of the variations in E-Commerce. .Although Trust Stance, Attitude Towards Online Shopping and Reputation are equally important in the growth of E-Commerce in the country, their effects are very minimal as against the other variables of sources of trust. This study collaborates with other studies done early in some developed counties [16]

\section{CONCLUSION}

The research focused on the empirical evidence of consumer sources of trust on E-Commerce of Ghana. The objective was to assess the impact of sources of trust on intention to purchase. It uses questionnaires with a total of 215 respondents for its analysis. The hypothesis set for this study was achieved, that is the sources of trust impact positively on the intention to purchase. The result shows that customer satisfaction, service quality and brand recognition should be the target of entrepreneurs in developing and expanding the ECommerce space in Ghana. They have much impact on the effects of consumer trust in Ghana. For E-Commerce to grow in Ghana continuously, then consumer trust dynamics should be watch carefully. Further studies is recommended for testing empirically electronic word of mouth (eWOM) in the Ghanaian situation.

\section{ACKNOWLEDGMENT}

We will like to express our heartfelt gratitude to Edward Opoku Mensah for his financial support to us in carrying out this studies. Also, to the national service personnel in the
Liberal Studies Department of Kumasi Technical University, Kumasi, Ghana for gathering the data for this research.

\section{REFERENCES}

[1] A.T. Kearney, The 2015 Global Retail E-Commerce Index: Global Retail E-Commerce Keeps On Clicking. Chicago: A.T. Kearney, 2015.

[2] A. Orendorff, Global Ecommerce, www.shopifyplus.com, Sep. 1, 2017 Access 10th Sep 2018

[3] W.T. Wang, Y.S. Wang, and E.R. Liu, "The stickiness intention of group buying websites: The integration of the commitment trust theory and ecommerce success model," Information \& Management, vol. 53(5), pp. 625-642, 2016.

[4] C.M. Chiu, E.T. Wang, Y.H. Fang, and H.Y. Huang, "Understanding customers' repeat purchase intentions in $\mathrm{B} 2 \mathrm{C}$ e-commerce: The roles of utilitarian value, hedonic value and perceived risk," Information System Journal, vol. 24(1), pp. 85-114, 2014.

[5] T. Oliveira, M. Alhinho, R. Paulo, and G. Dhillon, "Modelling and testing consumer trust dimensions in e-commerce," Computers in Human Behavior, vol. 71, pp. 153-164, 2017.

[6] A. Chowdhury, "Information Technology and Productivity Payoff in the Banking Industry: Evidence from the Emerging Markets," Journal of International Development, vol. 15(6), 2003.

[7] Y. Shi, C. Ling, and H. Chen, "Leveraging social grouping for trust building in foreign electronic commerce firms: An exploratory study," International Journal of Information Management, vol. 33(3), pp. 419428, 2013

[8] World Bank Statistics 2015.

[9] Africa Development Bank 2016.

[10] M.K. Kiang and K.H. Shang, Online purchase decision and its implication on e-tailing strategies. In New meanings for marketing in a new millennium. Springer International Publishing, 2015, pp. 212-217.

[11] A.H. Crespo and I.R.D. Bosque, "The influence of the commercial features of the Internet on the adoption of e-commerce by consumers," Electronic Commerce Research and Applications, vol. 9, pp. 562-575, 2010

[12] P. Palvia, "The role of trust in e-commerce relational exchange: A unified model," Information \& Management, vol. 46, pp. 213-220, 2009.

[13] J. Hair, W.C. Black, B.J. Babin, and R.E. Anderson, Multivariate Data Analysis, 7th ed.. Upper Saddle River, New Jersey: Prentice Hall, 2010.

[14] J.W. Hoelter, "The analysis of covariance structures: Goodness-of-fit indices," Sociological Methods and Researh, vol. 11, pp. 325-344, 1983

[15] A.M.. Abubakar, M. Ilkan, R.M. Al-Tal, and K.K. Eluwole, "eWOM, revisit intention, destination trust and gender," Journal of Hospitality and Tourism Management, vol. 31, pp. 220-227, 2017.

[16] T. Oliveria, Matilde Alhinho,Paulo Rita and Gurpreet Dhillon, "Modelling and Testing Consumer Trust Dimensions in E-commerce," Computers in Human Behavior, vol. 71, pp. 153-164, 2017. 